\title{
PUERTO DEL PENDULO, DOUBTFUL SOUND: THE MALASPINA EXPEDITION'S VISIT TO NEW ZEALAND IN QUEST OF THE TRUE FIGURE OF THE EARTH
}

\author{
Robert J. King
}

National Library of Australia

\begin{abstract}
The Malaspina expedition was assigned the task of conducting a series of experiments using the pendulum to measure the strength of gravity at different locations during the course of its voyage. The immediate objective was to establish the length of a pendulum beating at seconds at latitude $45^{\circ}$ as the basic unit of a new universal system of measures. Although the new unit, the metre, was eventually established on a different principle, the gravity experiments carried out by the expedition resulted in useful geodesic information and incidentally led to the first charting of Doubtful Sound in New Zealand.
\end{abstract}

KEY WORDS: Geodesy. Metric system. Malaspina, Alejandro. Scientific expeditions. New Zealand.

PUERTO DEL PENDULO, DOUBTFUL SOUND: LA VISITA DE LA EXPEDICIÓN MALASPINA A NUEVA ZELANDA EN BUSCA DE LA VERDADERA FORMA DE LA TIERRA

\section{RESUMEN}

La expedición Malaspina tuvo por misión realizar una serie de experimentos utilizando un péndulo para medir la fuerza de la gravedad en los diferentes lugares recorridos durante el viaje. El objetivo inmediato consistió en establecer la longitud de un péndulo oscilando durante unos segundos a una latitud de $45^{\circ}$ como unidad básica de un nuevo sistema métrico universal. Aunque la nueva unidad, el metro, fue finalmente establecida por otro principio diferente, los experimentos que llevó a cabo la expedición sobre la gravedad proporcionaron una información geodésica muy útil y por casualidad dieron lugar al primer trazado de mapa de Doubtful Sound, en Nueva Zelanda.

PALABRAS CLAVE: Geodesia. Sistema Métrico. Malaspina, Alejandro. Expediciones científicas. Nueva Zelanda. 


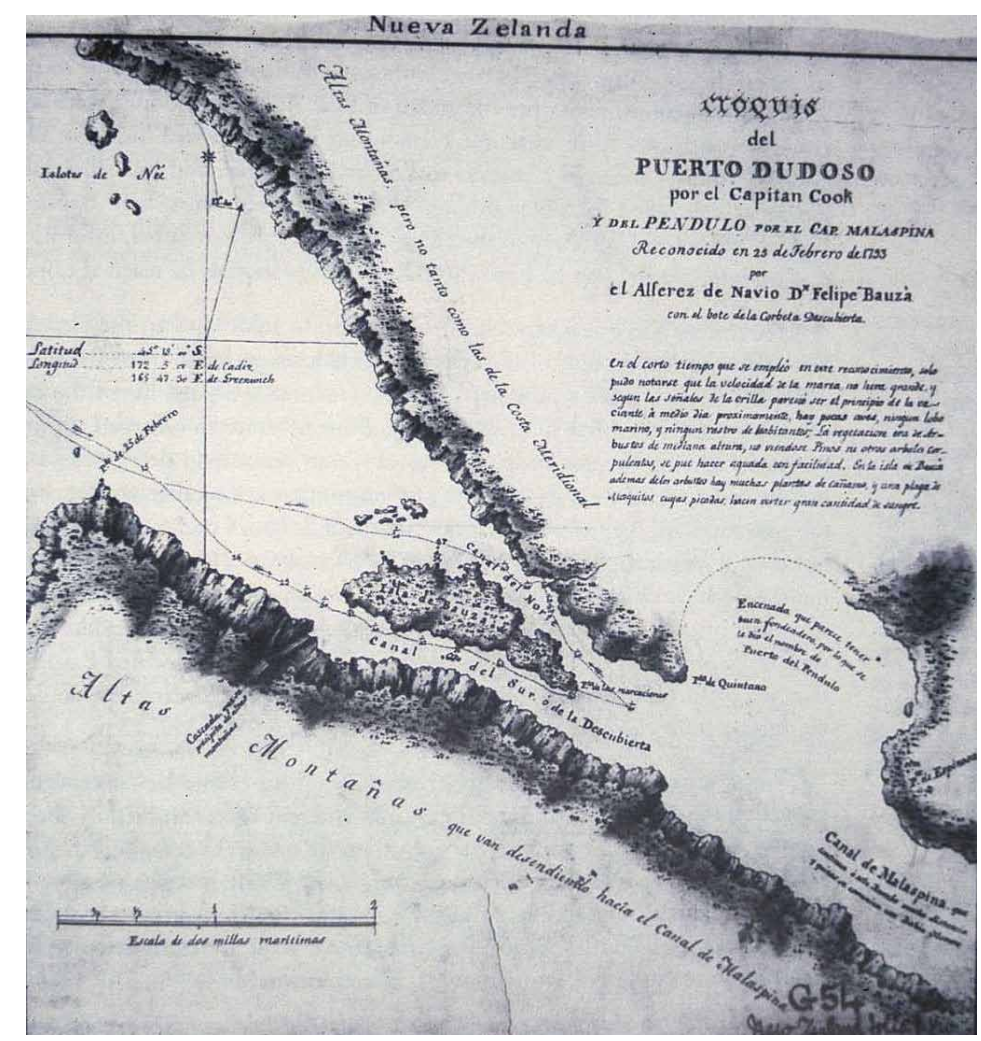

Croquis del Puerto Dudoso ... por el Alferez de Navio D ${ }^{\text {n }}$ Felipe Bauzà. UK Hydrographic Office, G54.

In April 1793, Thaddaeus Haenke, the naturalist with the expedition commanded by Alexandro Malaspina, wrote a letter to Sir Joseph Banks from Sydney Cove in Port Jackson, New South Wales, saying: «On the eleventh of March 1793, having been driven away from New Zealand by an extraordinary storm, we beheld with unanimous delight the coast of New Holland, and the following day the ships Descubierta and Atrevida with favourable winds approached Port Jackson». ${ }^{1}$

1 «Undecimo Martii die anni 1793, tempestate non mediocri a nova Zeelandia repulsi, littora novae Hollandiae unanimi voluptate conspeximus, dieque subsequenti ventis secundis naves Descubierta et Atrevida in portum Jakson appulere.» Haenke to Banks, 15 April 1793, 
The stormy weather mentioned by Haenke had prevented the expedition from carrying out the task for which it had gone to New Zealand, which was to undertake measurement of the force of gravity using a pendulum, one of a series of such observations done at different locations during the course of the voyage with the aim of ascertaining the true shape or figure of the Earth. ${ }^{2}$

The Malaspina expedition left Spain on 30 July 1789, as reported by the $G a$ zeta de Madrid of 18 August, which said: «The little fleet fitted out for the purpose of making discoveries, and commanded by Don Alexander Malaspina, sailed from Cadiz the 30th of last month. The expenses which the Court have been at in fitting out these ships, and furnishing them with various kinds of astronomical, mathematical, and physical instruments, for the intended voyage, proves how much his Majesty wishes to encourage and promote the Arts and Sciences. $»^{3}$ This report was subsequently carried in the press of other European

Staatsbibliothek zu Berlin-Preußischer Kulturbesitz (Sig: Sammlung Darmstädter Amerika (2): Haenke); published in the original Latin with a German translation by KÜHNEL, Josef (1960), Thaddeus Haenke: Leben und Wirken eines Forschers, München, R. Lerche; in Latin with a translation into Spanish by IBÁÑEZ, Victoria (1992), La Expedición Malaspina, 17891794, tomo IV, Trabajos Cientificos y Correspondencia de Tadeo Haenke, Barcelona, Ministerio de Defensa, Museo Naval y Lunwerg Editores; and in Latin with a translation into English in IBÁÑEZ, Victoria and KING, Robert J. (1996), A Letter from Thaddeus Haenke to Sir Joseph Banks, Sydney Cove, 15 April 1793, Archives of Natural History, 23 (2), pp. 255-260.

2 The astronomic, geodesic and hydrographic work of the expedition is discussed in MartíneZ-CaÑaVATE, Luis Rafael (1994), La Expedición Malaspina, 1789-1794, tomo VI, Trabajos Astronómicos, Geodésicos e Hidrográficos, Madrid y Barcelona, Museo Naval, Ministerio de Defensa y Lunwerg Editores. PIMENTEL, Juan (1998), La Física de la Monarquía: Ciencia y Política en el pensamiento colonial de Alejandro Malaspina (1754-1810), Aranjuez, Doce Calles, is an overall study of the expedition, and PIMENTEL, Juan (1992), En el Panóptico del Mar del Sur: Orígenes y Desarrollo de la Visita Australiana de la Expedición Malaspina (1793), Madrid, CSIC, is devoted to the visit of the expedition to Port Jackson (now Sydney), Australia. Selles, Manuel A. La Preparación científica e instrumental de la Expedición Malaspina, in OrozCo, Antonio (1991), La Expedición Malaspina (1789-1794). Bicentenario de la salida de Cádiz, Cádiz, Real Academia Hispanoamericana, pp. 69-81, limited his inquiry, saying: "Aquí sólo me he querido ocupar del proyecto inicial (...) Por ello, posiblemente se pueda echar a faltar algún que otro aspecto que fue posteriormente relevante, tal como, por ejemplo, el relativo al péndulo enviado posteriormente desde Paris y las mediciones con él efectuadas sobre la variación del valor de la aceleración de la gravedad en distintos lugares.» The present article is a more expansive discussion of an aspect of the expedition mentioned in the aforementioned works, i.e. the visit to New Zealand in connection with the pendulum experiments it was assigned to carry out.

3 Cádiz 8 de Agosto. «El dia 30 del pasado saliéron de este puerto las corvetas de la Marina Real Descubierta y Atrevida al mando del Capitan de fragata D. Alexandro Malaspina, 
countries, the foregoing version, for example, appeared in The Whitehall Evening Post of 10 September 1789.4 Another London newspaper, The Morning Star for 11 July 1789, had already carried an article describing the forthcoming expedition based on a letter from Malaspina to Sir Joseph Banks:

«The King of Spain has given orders for a voyage round the world, under the direction of the Chevalier Malaspina, an Italian, and captain of a frigate. The principal object of the voyage is to obtain exact hydrographic charts of the immense shores of the South Sea, and the Archipelago of the Philippines. But, desirous of seconding the efforts of other nations, in the improvement of Medicine and Natural History, as well as Geography and Navigation, the King has extended and enlarged the design of this voyage. Two vessels were ready to sail at Cadiz, the beginning of this month, having on board, botanists and painters, with excellent instruments for astronomy, land-surveying, and chemical experiments ... Most of the shores of Spanish America will be run over, the lands between Cape Horn and Chili, Pacific Ocean, the Marianes, the Carolines, the Philippines; and astronomical charts made of them. The Navigators will also be employed in studying the inhabitants and natural history of each country, in the manner of Capt. Cook and M. de la Perouse. $\rangle^{5}$

con destino á dar la vuelta al mundo. La magnificencia con que se ha habilitado esta expedicion es correspondiente al interes que el Rey toma en los progresos de las ciencias, y á la importancia del objeto, pues no se ha omitido dispendio ni medio alguno conducente. Se han construido expresamente los dos buques con todas las qualidades convenientes; se han dotado con una Oficialidad hábil y excogida, y con naturalistas, botánicos, y pintores de perspectiva y botánica, y va surtida de reloxes de longitud, chronómetros, muestras marinas, y unas preciosas colecciones de los mejores instrumentos de astronomía, matemática y física: de todos los libros de estas ciencias y de historia natural que se han considerado del caso; y en fin de quanto puede conducir al mas cabal logro de esta importante empresa, pues lleva hasta lo necesario para formar un hospital en qualquiera parte.»

4 The Diary, 9 September, the Gazette de France, 8 Septembre, The General Evening Post, 12-15 September, the September issues of The Gentleman's Magazine and The Political Magazine, and The Annual Register for 1789, also reported the expedition's departure, quoting reports from Cadiz of 12 August, and from Madrid of 18 August.

5 The Whitehall Evening Post, 14-16 July, The Diary, 15 July, The Times, 14 July, and The General Evening Post, 11-14 July, 1789, also carried more or less abbreviated versions of this article. «S.M. n'avoit d'abord d'autre objet dans cette expédition, que le travail des cartes hidrografiques de ses côtes presques immenses de la mer du Sud et de l'archipel de Filipines; mais désirant ensuite de seconder les efforts des autres nations pour les progrès de la phisique et de l'histoire naturelle, de même que pour ceux de la géographie et de la navigation, elle s'est daignée de donner la plus grande étendue a ce voyage. Deux corvêtes construites exprès, qui seront sous voile vers le premier de juillet, des botanistes, des peintres, des excellens instruments, soit pour l'astronomie, et pour la géodesie, comme pour la phisique.... Nous parcourirons la plus grande partie de l'Amérique Espagnole, les terres entre le Cap Hom et Chiloe, 
Malaspina indicated his intention to carry out gravity experiments in New Zealand at Dusky Sound in a letter he wrote from Acapulco in December 1791. ${ }^{6}$ Upon his arrival in Mexico he had received a letter from Antonio Valdéz, the Minister for the Marine and the Indies, dated 22 December 1790 and carried to Mexico by José de Espinosa y Tello and Ciriaco Cevallos. Valdéz wrote:

«As it is being endeavoured in France to set up a new system of weights and measures derived from the length of a pendulum that oscillates at seconds at the latitude of $45^{\circ}$, the King has judged it appropriate to take advantage of this opportunity to promote the progress of Geography and resolved that as the course of your voyage enables you to obtain information on this interesting point, you do so at convenient locations, so that it may be compared with that which has been verified in that Kingdom, and that knowledge concerning the actual figure of the Earth may be perfected by determining, if the southern hemisphere is more flattened, what may be this difference and others in the exterior shape of our globe, supposing its surface not to be as symmetrical as commonly imagined. As these points must be resolved by measurements of various degrees in different regions or by the observation of the pendulum in a certain number of locations, one that has been purposely constructed with the greatest care is being sent to you with Naval Lieutenants Don Josef Espinosa and Don Ciriaco de Cevallos. As in order to form an idea of the meridian the best way is to observe the pendulum in two locations proper for deducing the difference between them, His Majesty has resolved that the observations done at $45^{\circ}$ South are to repeat those already carried out at the same latitude North, to link our investigations with those of the French academicians.» ${ }^{7}$

une bonne partie des Isles de la mer Pacifique, les Marianes, les Carolines, et les Philipines, et nous endresserons des cartes astronomiques, mais nos recherches pourroient pousser plus loin; elles pourroient suivre les traces, que les dernieres voyageurs et particulièrement mrs Cook et Lapérouse, nous ont laissées.» Malaspina to Sir Joseph Banks, 20 January 1789, British Museum, Add. Ms. 8097: 216-20.

6 Malaspina à Paolo Greppi, 20 Decembre 1791, published in MANFREDI, Dario (1999), Alessandro Malaspina e Fabio Ala Ponzone: Lettere dal Vecchio e Nuovo Mondo (17881803), Bologna, il Mulino, p. 294.

7 «Tratándose en Francia de arreglar un sistema de pesos y medidas derivado de la longitud del péndulo que oscila los segundos en la latidud de $45^{\circ}$ : el Rey ha juzgado conveniente aprovechar esta coyuntura para promover los progresos de la geografía; y ha resuelto que pues el curso de su viage le proporciona á V.S. hacer observaciones sobre este interesante punto. Las execute en los lugares convenientes, para que comparadas con las que han de verificarse en aquel reyno, puedan perfeccionar los conocimientos actuales sobre la verdadera figura de la tierra, determinando si el hemisferio meridional es mas aplanado, ¿quál sea esta diferencia y las demas que pueda haber en la forma exterior de nuestro globo, supuesto que su surperficie no sea tan simétrica como comunmente se imagina? Como estos puntos han de resolverse por 
The French initiative referred to by Valdéz originated with a report presented to the French National Assembly by Charles Maurice de TalleyrandPérigord on 9 March 1790. Recommending reform and reduction to uniformity of the immense confusion of weights and measures traditionally used in France, Talleyrand emphasized that it was necessary for a perfect solution to the problem that the basic standard to be adopted should be referable to an invariable model taken from nature, which could be returned to in case the standard needed to be checked or altered at some future time. Having reviewed the several alternatives put forward by leading savants, Talleyrand gave preference to that which consisted of taking «for the elemental measure, the length of the pendulum at seconds in the latitude of $45^{\circ} »$, as «the numerous partisans of that method have preferred this point, as being the mid-term between the Equator and the Pole». He also drew attention to current English interest in the problem, and recommended that determination of the new standard be a joint Anglo-French undertaking, which would contribute to its gaining universal acceptance among the nations. ${ }^{8}$ He was also aware that the reform of weights and measures was a current issue in the United States of America, and that Thomas Jefferson, former ambassador to France and cu-

las medidas de varios grados en diferentes regiones, ó por las observaciones del péndulo en cierto número de lugares, conducen á V.S. uno, construido de intento con el mayor cuidado, los Tenientes de Navío Don Josef de Espinosa y Don Ciriaco Cevallos. Pues que para formar idea de la figura del meridiano es el mejor medio el del exámen del péndulo en dos lugares propios para deducir la alteracion que ha tenido, ha resuelto S.M. que á su tiempo se repitan á $45^{\circ} \mathrm{S}$. las observaciones que se practiquen ahora á igual latidud N. para ligar nuestras investigaciones con las de los Académicos franceses. El Capitan de Fragata Don Josef de Mendoza, que ha de concurrir con ellos á las observaciones que han de practicarse, me ha remitido el papel adjunto para govierno de V.S. » Letter of Valdéz to Malaspina, 22 December 1790, accompanying his sending of a pendulum to him care of José de Espinosa y Tello and Ciriaco Ceballos, Archivo General de Marina (Madrid), Sección Histórico, legajo 45: quoted in EsPINOSA Y TELLO, Josef (1809), Memorias sobre las Obervaciones Astronómicas, hechas por los Navegantes Españoles en Distintos Lugares del Globo, (Madrid, Imprenta Real, tomo I, pp. 190-191); and in PORRUA, Enrique J. (ed.), (2001), The Diary of Antonio de Tova on the Malaspina Expedition, 1789-1794, Lewiston, Queenston and Lampeter, p. 453. SANFELIÚ ORTIZ, Lorenzo (1943 y 1988), 62 meses a bordo: La expedición Malaspina según el diario del Teniente de Navio Don Antonio de Tova Arredondo, 2. ${ }^{\circ}$ Comandante de la «Atrevida» 1789-1794, Madrid, Editorial Naval, pp. 137-138; cited in Higueras RodrígueZ, M. ${ }^{a}$ Dolores (1999), La Expedición Malaspina, 1789-1794, tomo IX, Diario General del Viaje Corbeta Atrevida por José Bustamante y Guerra, Barcelona y Madrid, Museo Naval, Ministerio de Defensa y Lunwerg, pp. 26-27.

8 Proposition sur les poids et mesures faite à l'Assemblée national, par M. de Talleyrand-Périgord, évêque d'Autun, Archives Parlementaires, 9 Mars 1790, pp. 106-108. 
rrent Secretary of State, was an advocate of reform. Jefferson recommended in a report he submitted to the House of Representatives on 13 July 1790: «Let the standard of measure, then, be a uniform cylindrical rod of iron, of such length as, in latitude $45^{\circ}$, in the level of the ocean, and in a cellar, or other place, the temperature of which does not vary throughout the year, shall perform its vibration, in small and equal arcs, in one second of mean time». ${ }^{9}$

Christiaan Huygens, the inventor of the pendulum clock, proposed in 1673 using the length of a pendulum beating at seconds as the basic unit for a universal measure «which, once agreed upon, could not only be established by people everywhere, but also in times to come be reconstituted». ${ }^{10}$ Huygens' colleague at the Académie Royale des Sciences, the Abbé Jean Picard, supported this proposal. Picard had measured an arc of the Meridian of Paris between Malvoisine and Sourdon in 1669, and established the length of a degree of latitude as 57.06 toises (111.3 metres). His unit of measurement, the toise, did not have a perfectly preserved standard (it varied from time to time and from place to place throughout France), and Picard recognized the virtue of a standard that could be recovered if necessary by making it referable to an invariable feature of nature, and the length of a pendulum beating at seconds fitted this criterion. ${ }^{11}$ In 1742, during the course of a scientific expedition to what is now Ecuador to ascertain the shape of the Earth, Charles-Marie de la Condamine established the length of a pendulum beating seconds on the Equator near Quito, and he proposed this as the universal unit of measure: «mensurae naturalis exemplar, utinam et universalis». ${ }^{12}$

9 Thomas Jefferson, Plan for establishing uniformity in the Coinage, Weights and Measures of the United States, July 13, 1790, in BERGH, Albert Ellery (ed.), (1907), The Writings of Thomas Jefferson, vol. III, Washington, pp. 25-32.

10 Huygens, Christiaan (1673), Horologium Oscillatorium, The Hague, pp. 152-154, Propositio xxv, De mensure universalis, \& perpetuae, constituendae ratione.

11 DANSON, Edwin (2006), Weighing the World: the Quest to measure the Earth, New York, Oxford University Press, p. 27.

12 «A natural and, may it be an universal, model of measure», from the inscription engraved on the commemorative marble plaque he presented to the Jesuits' Church of San Francisco in Quito in 1742: LA CONDAMINE, Charles-Marie De (1751), Journal du Voyage fait par Ordre du Roi à l'Équateur, Paris, Imprimerie Royale; and LA Condamine, Charles-Marie De (1747), Nouveau Projet d'une Mesure invariable propre à servir de mesure commun à toutes les Nations, Mémoires de l'Academie Royale des Sciences, pp. 489-514. See also LAFUENTE, Antonio and Delgado, Antonio J. (1984), La Geometrización de la Tierra: Observaciones y Resultados de la Expedición Geodésica Hispano-Francesa al Virreinato del Perú (1735-1744), Madrid, CSIC, pp. 258-264. See also HumBoldT, Alexander von (1845), Kosmos: A General Survey of Physical Phenomena of the Universe, translated by A. Prichard, London, Baillière, vol. I, p. 422. 
The National Assembly debated Talleyrand's report on 8 May 1790, and adopted his recommendation. The resolution of the Assembly was reported in the English press:

8 May 1790. It was this evening decreed -

«That the President do wait on the King, and request him to write to his Brittannic Majesty for his concurrence in the project of establishing an universal standard of weights and measures; and that an equal number of the Royal Society of London, and of the Academy of Sciences in Paris may be appointed, by authority of Parliament and of the National Assembly, to ascertain the length of the pendulum, at 45 degrees latitude, or elsewhere.» ${ }^{13}$

The addition of the phrase «or elsewhere» to the resolution was intended to mollify the English, who preferred the latitude of Greenwich $\left(51^{\circ} 28^{\prime} \mathrm{N}\right)$ and Jefferson, who preferred the mid-point between the northern and southern boundaries of the United States $\left(30^{\circ} \mathrm{N}\right) .^{14}$

The Spanish naval officer and astronomer, José Mendoza y Ríos, was already working closely with the French savants (having been sent to France and several other European countries as leader of a delegation of Spanish officers charged with obtaining information on advances in astronomy and navigation), and Valdéz said in his letter to Malaspina that it was on his recommendation that it had been decided to add the task of measuring the figure of the earth to the expedition's mission. Mendoza procured in London the specially made pendulum that Valdéz sent to Malaspina in Mexico. ${ }^{15}$ There was also perhaps the idea that this would fulfill the task that the loss of the Lapérouse expedition had left uncom-

13 The Times, 15 May 1790. «Assemblée Nationale, Séance du Samedi soir 8 Mai Décrète ensuite que le Roi sera également supplié d'écrire à Sa Majesté Britannique, et de la prier d'engager le Parlement d'Angleterre à concourir avec l'Assemblée Nationale, à la fixation de l'unité naturelle des mesures et des poids: qu'en consequénce, sous les auspices des deux Nations, des Commissaires de l'Académie des Sciences de Paris pourront se réunir en nombre égal avec des Membres choisis de la Société royale de Londres, dans le lieu qui sera jugé respectivement le plus convenable, pour déterminer, à la latitude de 45 degrès, ou toute autre latitude qui pourroit être préferée, la longueur du pendule, et en déduire un modèle invariable pour toutes les mesures et pour les poids.» Le Moniteur Universel, 10 Mai 1790, p. 526.

14 Archives Parlementaires, 9 Mars 1790, pp. 106-108; 8 Mai 1790, p. 438-440; Le Moniteur Universel, 30 Avril et 10 Mai 1790; cited in ALDER, Ken (2002), The Measure of Things: the Seven Year Odyssey that Transformed the World, London, Little, Brown, pp. 90-99.

15 Valdéz to Malaspina, 22 December 1790; cited in Porrua, p. 453. Valdéz to Aranda, 15 April 1792, Museo Naval, Madrid, legajo 2294, doc. 1; cited in TEN, Antonio (1989), El sistema métrico decimal y España, Arbor, 134, pp. 109-110. 
pleted. The Times of 7 May 1788 reported that «M. Dagelet», of the Academy of Sciences, who went with the Lapérouse expedition as its astronomer, «was particularly directed to make observations with the pendulum, to determine the differences in gravity, and to ascertain the true proportion of the equatorial to the polar diameter of the earth». ${ }^{16}$ A later article published after reports from Lapérouse had been received from Petropavlovsk in Kamchatka said that, «Mr. Lepaute d'Agelet, astronomer of the expedition, has made observations on the length of the simple pendulum, to determine the force of gravitation, in climates where none such were made before». ${ }^{17}$ At Botany Bay, Dagelet urged William Dawes, the new colony's astronomer, to attempt «la mesure d'un degré du meridien sous cet hemisphere»». ${ }^{18}$ Malaspina referred to Joseph Dagelet several times in his journal, and while at Manila in March 1792 noted: «Now, as on many other occasions, we regretted that we did not have the results of M. Dagelet's calculations on the ill-fated expedition of Count de la Peyrouse, although we had no doubt that they would have been similar to our own». ${ }^{19}$

Malaspina referred to his receipt of the pendulum and letter from Valdéz in an entry in his journal for 21 April 1791:

16 «Une des recherches les plus intéressantes est celle qui concerne la determination de la longueur du pendule à secondes, à differentes latitudes. Les inductions que l'on a tirées jusqu'ici de cet instrumen, pour determiner les variations de la Pesanteur, ont en pour fondement des opérations faites en petit nombre par divers observateurs, avec des instrumens différens; et ce defaut d'uniformité dans les operations a dú influer sur la certitude des conséquences déduites de la comparaison des résultats. On sent de quel prix serait un ensemble d'opérations de ce genre, faites avec soin, par les mêmes personnes, et avec les mêmes instrumens.» Mémoire rédigé par l'Académie Royale des Sciences pour servir aux Savans embarqués sous les ordres de M. de La Pérouse, 8 Juin 1785, L.A. Milet-Mureau (red.), Voyage de La Pérouse autour du Monde, Paris, 1797, vol. I, p. 158.

17 Report from Paris of 1 March 1789 in The Morning Post and The Whitehall Evening Post (London), 7 March 1789; The Pennsylvania Mercury (Philadelphia), 14 May 1789.

18 Dagelet à Dawes, à la Baye Botanique, 3 Mars 1788, State Library of New South Wales (Sydney), Mitchell Ad 49/6-7.

19 «Aora, como en muchas otras Ocasiones, echaramos a menos, para la devida Comparacion los Resultados del Sr. Dagelet en la desgraciada Expedicion del Conde de la Peyrouse; bien que no dudaramos, que huviese precisamente de aproximarse a las determinaciones ya indicadas.» Cerezo Martínez, Ricardo y SAnz Álvarez, Carmen (1990), La Expedición Malaspina, 1789-1794, tomo II, Diario General del Viaje por Alejandro Malaspina, Barcelona y Madrid, Museo Naval, Ministerio de Defensa y Lunwerg, vol. 2, p. 47; DAVID, Andrew, Fernandez-Armesto, Felipe, Novi, Carlos, Williams, Glyndwr (2003), The Malaspina Expedition, 1789-1794: the Journal of the Voyage by Alejandro Malaspina, London and Madrid, Hakluyt Society in association with the Museo Naval, vol. II, p. 303. 
«According to the official letter to me from his Excellency the Minister of the Marine, by means of this Pendulum the Gravitation experiments at different Parallels of the Earth should be repeated as much as possible, not only for a Regulation of Measures which would depend on the consistent Observations which would in due course be verified in Europe exactly on the Parallel of $45^{\circ}$, but also in order to carry on the investigations as to the true figure of the Earth in which there was suspected, not without basis, to be some variations from one Hemisphere to the other.. ${ }^{20}$

He initially intended to perform the pendulum experiments in New Zealand at Dusky Sound, as he said in the letter he wrote from Acapulco in which he set out the itinerary he then proposed to follow, «proceeding to New Holland, skirting around it by the West coast and doing gravity experiments in its most southerly parts; I will repeat these at Dusky Bay in New Zealand».21 This itinerary was subsequently revised, and after leaving the Philippines he changed the preferred location to Doubtful Sound, as he recorded in his journal on 16 February 1793: «In a Latitude so close to that of 45 degrees as was Dusky Bay, and even more so Doubtfull-Bay which I intended to examine, our Experiments must be considered to be highly useful for the proposed objective of a common measure for all the European Nations». ${ }^{22}$

On 25 February 1793, the two ships of the expedition found themselves off the entrance to Doubtful Sound but, as recorded by Antonio de Tova, the second in command of the Atrevida, an island at the mouth of the Sound hid from view its interior, and «presented to our view were only two arms or channels, which appeared to lead on one side or the other into it». He explained:

20 «Segun me lo prevenía en Oficio particular el Excmo. Sr. Ministro de Marina devían repetirse, quanto fuese posible por medio de dicho Pendulo, las Esperiencias de la Gravedad de los Cuerpos en differentes Parelelos de la Tierra, no solo para un Arreglo de Medidas, que dependiese del mismo Cotejo de Observaciones, que en el dia devían verificarse en Europa justamente en el Parelelo de $45^{\circ}$, sí tambien para continuar en las pesquizas de la verdadera figura de la Tierra, el la qual, no sin fundamento, se sospecharan algunas desigualdades de uno a otro Emisferio.» CEREZo MARTíneZ (1990), vol. 1, p. 271; DAVID (2003), vol. II, p. 66.

21 «Passer à la Nouvelle Hollande, la cotoyer par son côté de l'ouest et faire les expériences de la gravité dans ses parties les plus méridionales; je les répèterai à Dusky Bay dans la Nouvelle Zélande.» Malaspina à Paolo Greppi, 20 decembre 1791, published in MANFREDI (1999), p. 294.

22 «En una Latitud tan imediata a el grado 45, como lo era la de Dusky Bay, o mucho mas la de Doubtfull-Bay que me proponía examinar, nuestras Experiencias devían precisamente mirarse, como de una utilidad tan grande para el fin propuesto de la medida comun a todas las Naciones Europeas.» CEREZo MARTínEZ, (1990), vol. 2, p. 164; DAVID (2004), vol. III, p. 56. 
«The high, steep configuration of the terrain close to the entrance, the narrowness and winding of the channels and, as well, finding no bottom after sounding to a depth of 120 brazas [about 120 fathoms or 200 meters], were reason enough to make it imprudent to attempt to enter this port, which otherwise would have been suitable because of its situation so close to the $45^{\circ}$ parallel for conducting the experiments with the pendulum proposed by the Commander..${ }^{23}$

On the afternoon of 25 February, while Descubierta remained off the entrance, Malaspina sent the expedition's cartographer, Felipe Bauzá, with the Descubierta's boat into the Sound to carry out a survey of it. ${ }^{24}$ Bauzá produced a fine chart of the lower parts of Doubtful Sound, assigning the name «Puerto del Pendulo» to "an inlet that appears to have a good anchorage» which is in fact the junction of two bodies, later called Thompson Sound and Bradshaw Sound, with Doubtful. On modern charts this area is called Pendulo Reach. The upper part of the Sound, which he did not have time to survey, he named «Canal de Malaspina», which he wrongly thought might connect with Dusky Sound. He inscribed a description of Doubtful Sound on his chart:

«In the short time employed in this survey, it could only be noted that the tidal current was not great, and from the signs on the shore it appeared that the beginning of the ebb was around midday; there were few birds, no seals, and no trace of inhabitants. The vegetation was bush of a middling height, no Pines or other large trees could be seen; watering could be done easily. On Bauza Island, besides bushes there were many flax plants and a plague of Mosquitoes whose bites drew a quantity of blood.»

In his journal, Malaspina recorded a similar description, and also that he assigned the name «Puerto del Pendulo» to the area below Bauza Island, which he called «Isla de el Medio», and called the upper part of the Sound «Canal Escarpado» from the steepness of its shores. Bauzá's «Puerto del Pendulo», he called «Puerto de Bauzá». He wrote that Haenke recognized the predominant vegetation, a species of southern beech (Nothofagus spp.) like the ñirre found in southern Chile. He thought it to be a less comfortable, se-

23 «La configuración de las tierras inmediatas a la boca, altas y escarpadas hasta el mar, la angostura y tortuosidad de los canales, y, por último, el no encontrarse fondo con 120 brazas de sondaleza, eran todas razones que hacían imprudente una tentativa con las corbetas para tomar este puerto, a lo cual convidaba, por otra parte, su situación próximamente en el paralelo de $45^{\circ}$ exactamente, a propósito para verificar las experiencias del péndulo simple que el Comandante se proponía.» SANFELIÚ ORTIZ, (1943 y 1988), p. 242; PORRUA (2001), p. 476.

$24 \mathrm{M}^{\mathrm{C}} \mathrm{NAB}$, Robert (1907), Murihiku and the Southern Islands, Invercargill, South, pp. 49-56. 
cure or healthy port than Dusky Sound and therefore destined to remain forever deserted. ${ }^{25}$ Eventually, it was Bauzá's names that remained, or were reinstated on the charts. In 1797, Bauzá was appointed Sub-Director of the Dirección de Hidrografía in Madrid, where he commenced to assemble a collection of maps and papers relevant to his ambition to compile a set of definitive atlases of the territories of the Spanish Monarchy in Europe and America. From 1815 he was Director of the Dirección de Hidrografía, but in 1823 was forced by political turmoil in Spain to flee to England, where he died in 1834. In England, he worked with the Hydrographic Office, and on 10 February 1830 he presented it with his chart of Doubtful Sound. It thereby became the basis for British Admiralty, and subsequently New Zealand Geographic Board, charts of the Sound. ${ }^{26}$ The New Zealand Geographic Board has now restored the Spanish place-names that had been displaced by later surveyors, and today these form a unique cluster of the only Spanish names on the map of New Zealand: Febrero Point, Bauza Island and the Nee Islets, Cascada bay, Quintano Point, Espinosa Point, Pendulo Reach and Malaspina Reach. On 22 September 1984 a plaque was unveiled at Marcaciones Point, the site of Bauzá's observation station for his chart of Doubtful Sound and of the first Spanish landing in New Zealand. ${ }^{27}$ Though disappointed in its principal aim in

25 «Seguía luego a el ESE un Canal de dos a dos y medio Cables formado en los mismos Montes, los quales caían estremadamente a pique, y ultimamente el Canal mucho mas estrecho, torcía mas a el S, a encontrar tal vez los terminos de los Canales Internos de Dusky-Bay: no se advertía una grande velocidad en la Marea: Segun las Señales en la Orilla, parecía el principio de la vaciante proximamente a el medio dia: Muy Pocas Aves, ningun Lovo Marino, solas algunas Lapas chicas, por lo que toca a Marisco, y ningun rastro, aunque remoto, de Abitantes, eran las demas circunstancias dignas de atencion en este aquel Puerto, al las quales, devía luego añadirse la falta total del Pino, componiendose, allí la Vegetacion de una especie de Arbusto de mediana altura, que D. Tadéo Heneke llamo [-] En el total sino son las experiencias del Pendulo simple, ò una verdadera necesidad las que guien algun Navegante a este Puerto, debemos creer que està destinado à ser perpetuamente desierto, y que Dusky-Bay sera siempre la que convide en estas inmediaciones à sus orillas, con un abrigo mas comodo, mas seguro y mas sano. El Puerto tuvo el Nombre de Pendulo Simple: La abra interior la de Bausá: La Isla esterior de la Isla de el Medio: y el Canal Interno el de Canal Escarpado». CEREzo MARTíNEZ (1990), vol. 2, p. 165; DAVID (2004), p. 57.

26 DAVID, Andrew (1994), Felipe Bauzá and the British Hydrographic Office, 1823-1834. In Palau Baquero, Mercedes y Orozco Acuaviva, Antonio (eds.), Malaspina '92: I Jornadas Internacionales - Madrid, Cádiz, La Coruña. 17-25 de Septiembre de 1992, Cádiz, Real Academia Hispano-Americana, pp. 235-242.

27 Hall-Jones, John (2002a), Doubtfull Harbour, Invercargill, Craig Printing, 1984 and 1988 supplement; HALL-JONES, John (2002b),, The fjords of Fiordland, Invercargill, Craig Printing. 
going there, namely to conduct observations of gravity with the pendulum, the expedition's survey of Doubtful Sound did make its addition to the sum of knowledge of the South West coast although, as Malaspina predicted, the area remained mostly uninhabited.

In the first published report on the results of the expedition, in the Gazeta de Madrid of 12 December 1794, the gravitational experiments and their anticipated contribution to the establishment of a new metric system were given particular mention:

«The gravitation experiments, repeated in both hemispheres and at various latitudes, will conduce to important confirmation of the non-symmetrical figure of the earth, and will be the basis of a universal, verifiable measure, as constant as the laws on which it depends, that is intended to be established in Europe.. ${ }^{28}$

It is curious that the article said that the gravity experiments would be the basis of a universal standard «that it is intended be established in Europe». That was thought to be the case when Valdéz sent the pendulum to Malaspina in December 1790, on the basis of the resolution of the French National Assembly of 8 May. The British Foreign Secretary the Duke of Leeds had responded from London on 3 December 1790 to the invitation from the National Assembly for collaboration: "There has often been question of such an arrangement among our public Economists but the Project seems exposed to so many Difficulties that its Accomplishment, however desirable it may be, has been regarded as almost impracticable». ${ }^{29}$ No doubt in part because of this rebuff from the English, the French resolved to make the establishment of the new system of measurement a national project, and on 26 March 1791 the National Assembly adopted as the criterion for the universal measure one ten-

28 «Las experiencias sobre la gravedad de los cuerpos, repetidas en ámbos hemisferios y á diversas latitudes, conducirán á importantes averiguaciones sobre la figura no simétrica de la tierra, y serán el fundamento de una medida como se pensó extablecer en Europa, universal, verificable y tan constante como las leyes de que depende.» Gazeta de Madrid, 12 de Diciembre de 1794. A translation of this article was published in the American press, such as The City Gazette (Charleston, South Carolina), 19 July 1797; The Massachusetts Spy, 13 September 1797; The Albany Chronicle, 25 September 1797; and The Oracle of Dauphin, 22 December 1797.

29 Quoted in TeN, Antonio E. (1993), L'Academie des Sciences et les Origines du Système Métrique Décimal. In DÉBARBAt, Suzanne et TEN, Antonio E. (eds.), Mètre et Système Métrique, Valencia, Observatoire de Paris/Instituto de Estúdios Documentales e Históricos sobre la Ciencia, Universitat de València, p. 25. 
millionth the distance from the Pole to the Equator as determined by extrapolation from the measurement of an arc of the Meridian of Paris between Dunkirk and Barcelona. ${ }^{30}$ Thomas Jefferson was irritated by the substitution of a standard drawn from a feature particular to the terrain of France, saying, "If other nations adopt this unit, they must take the word of the French mathematicians for it's length», and refused to have anything more to do with it. ${ }^{31}$

Observations of gravity were made during the course of the expedition at fifteen locations in the northern and southern hemispheres (Acapulco, Port Mulgrave in Alaska, Nootka, Monterey, Guam, Manila, Macao, Zamboanga, Port Jackson, Vava'u, Lima, Concepcion, Port Egmont in the Falklands Malvinas, Puerto Santa Elena in Patagonia and Montevideo). Ciriaco Cevallos was able to correlate these when the expedition arrived at Montevideo in February 1794, and they confirmed that the figure of the earth was not symmetrical in both hemispheres, as it was possible to detect with the pendulum a stronger gravitational pull in the South. ${ }^{32}$ This finding, which corroborated that of Nicolas Louis de la Caille who carried out observations at the Cape of Good Hope in 1750-1752, invalidated the premise which underlay the French decision to derive the universal measure from an arc of the Meridian of Paris on the assumption that it was exactly the same as every other meridian of the earth. ${ }^{33}$ The results of the gravity observations were analysed by Gabriel Ciscar, who found the experiments revealed a different strength of gravity, a different length of pendulum and different eccentricity (aplanamiento) of the Earth for the different locations. He attributed these irregularities to «the heterogeneity of the strata of our globe, to some slight errors in the observations and

30 Archives Parlementaires, 9 Mars 1790, pp. 106-108; 8 Mai 1790, p. 438-440; Le Moniteur Universel, 30 Avril et 10 Mai 1790; cited in ALDER (2002), pp. 90-99.

31 Jefferson, Thomas (1792), Memorandum to James Munroe. In Boyd, Julian P. (ed.) (2002), The Papers of Thomas Jefferson, vol. 27, Princeton U.P., 1950-, pp. 818-822; cited in ALDER, (2002), p. 100.

32 «Imediatamente despues se emprendieron las Experiencias de la Gravedad en el Pendulo Simple, y para los ultimas dias del Mes yá terminadas tambien estas, pudo el Theniente de Navío Don Ciriaco Zevallos, sistemar todas las que se havían echo en uno, y otro Emisferio, de las quales resultara (como lo havía ya sospechado el Abate La Caille) una mejor gravedad en el Emisferio Austral que en el Boreal». Cerezo Martínez (1990), vol. 2, p. 300; Malaspina, journal entry for 20 February 1794, DAVID (2004), vol. III, p. 239.

33 Ciriaco Cevallos a Félix de Tejada, Inspector General de Marina, 28 November 1795, Archivo Naval (Madrid), ms. 2296, f. 228; cited in GonZÁLEZ ClaVERÁn, Virginia (1988), La Expedición Científica de Malaspina en Nueva España, 1789-1794, México DF, El Colegio de México, p. 271. 
to some small, irregular alteration in the length of the supposedly invariable pendulum». ${ }^{34}$ The observations contributed to the dawning realization that the figure of the Earth was so irregular as to be beyond ascertainment by simple extrapolation, a conclusion subsequently expressed by Alexander von Humboldt: "The true figure of the Earth stands in relation to a regular figure 'as the uneven surface of ruffled stands to the even surface of unruffled water'». ${ }^{35}$ The 1792-1798 survey carried out by Jean-Baptiste Delambre and Pierre Méchain to measure the Dunkirk-Barcelona arc confirmed the irregularity of the figure of the earth. As Méchain put it: «The earth has refused to conform to the formulae of my mathematical colleagues, who have insisted until now, with absolute certainty, that it is a perfectly regular spheroid of revolution». ${ }^{36} \mathrm{An}$ International Commission for Weights and Measures was convened in Paris to settle the true length of the metre, at which Ciscar participated as a member of its sub-committee on the arc of the meridian. ${ }^{37}$ Rejecting the DelambreMéchain survey, the standard metre adopted by the International Commission on 22 June 1799 was based on the findings of La Condamine and his colleagues during the 1736-1742 expedition to Peru, i.e. the length of a pendulum beating seconds on the Equator near Quito: this fell short of one-ten millionth the distance between the Equator and the North Pole, the actual distance was later found to be some 10,003,250 of the new metres. The 1799 metre was replaced in 1875 by a new metre based on it, the definition of which omitted any referen-

34 Espinosa y Tello (1809), tomo I, pp. 190-212, Experiencias sobre la gravedad hechas con un péndulo invariable en los puertos de Europa, América y Asia, mar Pacífico y Nueva Holanda en el viage de las corbetas Descubierta y Atrevida... calculadas por Don Gabriel de Ciscar). This book was studied in the Russian Navy: see «Изве̌стіе о Испанской Экспедиціи Предпринятой лдя Откытіи въ 1791, 1792 и 1793 годахъ подъ командою Капитана Малесепине», Записки, издаваемыя Государственнымъ Адмиралтейскимъ Департментомъ, относящіяся къ Мореплаванію, Наукамъ и Словесности ('Izvestie о Ispaniskoi Ekspeditsii Predipritnyatoi dlya Otkritii v' 1791, 1792 i 1793 godakh pod' komandoyu Kapitana Malespine', Zapiski, izdavayemiya Gosudarstvennim Admiralteiskim Departmentom, otnosyashchiyasya $k$ ' Moryeplavaniyu, Naukam i Slovesnosti - 'News on the Spanish Discovery Expedition of 1791, 1792 and 1793 commanded by Captain Malespina', Notes issued by the State Admiralty Department relating to Navigation, Science and Literature), II, 1815 , pp. 256-260.

35 Humboldt (1845), vol. I, p. 179.

36 Méchain to Rolland, 11 May 1799, Isidore Dougados, Lettres de l'astronome Méchain à M. Rolland, Mémoires de la Société des Arts et des Sciences de Carcassonne, vol. 2, 1856, p. 101; cited in ALDER, (2002), p. 263.

37 LóPEZ SÁNCHEZ, Juan Francisco y VALERA CANDEL, Manuel (1994), Gabriel Ciscar en el Congreso de Unificacion de Pesas y Medidas de Paris de 1798, Asclepio, 46 (1), pp. 3-35. 
ce to the shape of the Earth. ${ }^{38}$ The most recent definition of the metre was adopted at the Conférence Générale des Poids et Mesures, October 1983: «Le mètre est la longueur du trajet parcouru dans le vide par la lumière pendant une durée de 1/299 792458 de seconde».

Fecha de recepción: 5 de junio de 2008

Fecha de aceptación: 4 de marzo de 2009

38 ALDER (2002), pp. 246-265, 351-356. 